\title{
関係分類における依存木上の重要トークンの自動判別
}

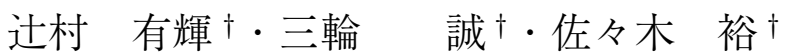

本稿では関係分類における入力トークンの重要性を学習し, 不要な情報をマスクす るマスク機構を提案する。 入力文の依存木上における, 注目エンティティ間を結ぶ 最短経路上には関係分類において重要な情報がよく存在するため, 関係分類の特徴 の一つとしてよく利用される。しかし，このヒューリスティックは所有格の $s$ のよ うに, 最短経路外に重要なトークンが存在するような例外に対してはあてはまらな い. そこで本研究では重要なトークンの判別規則を学習する機構を導入しそのよう な事例に対応する。学習は夕スク損失から End-to-Endに行われ, 追加アノテーショ ンは必要ない。実験の結果, 提案手法は最短経路のヒューリスティックを上回る識 別性能を記録した。 また, 提案機構が学習するマスクは最短経路と高い類似度とな る一方, 所有格の $s$ など最短経路外の重要なトークンも利用するよう学習された.

キーワード：関係分類, 依存木, マスク

\section{Automatic Detection of Important Tokens on Dependency Trees for Relation Classification}

\author{
Tomoki Tsujimura ${ }^{\dagger}$, Makoto Miwa $^{\dagger}$ and Yutaka Sasaki ${ }^{\dagger}$
}

\begin{abstract}
This paper proposes a masking mechanism that learns the importance of each input token and masks unnecessary tokens for relation extraction. As a feature of relation classification models, the shortest path between target entities in the dependency tree of an input sentence is often employed since it is known to well capture important information for relation classification. However, this heuristic rule is inapplicable to exceptional relation expressions such as relations that require tokens outside of the path (e.g., the possessive "s"). We handle such inflexibility by employing a novel masking mechanism that learns a masking rule of important tokens. We performed the training in an end-to-end manner by using the loss of the relation classification task without the need for additional annotations. The experimental results show that our proposed method shows better classification performance than the models with the shortest path heuristics. Furthermore, the learned masks highly correspond to the shortest paths, while capturing some important tokens outside the shortest paths such as possessive "s".
\end{abstract}

Key Words: Relation Classification, Dependency Tree, Masking

†豊田工業大学, Toyota Technological Institute

本論文の一部は, 言語処理学会第 25 回年次大会とNLP 若手の会第 11,14 回シンポジウムで発表したものです. 


\section{1 はじめに}

本稿ではニューラル関係分類モデルの中間表現中の不要な情報の除去に取り組む。関係分類と は，文書内のエンティティのペア間について，その文書内の言及に基づいた関係を識別するタス クである，本研究では特に一文中に存在するエンティティペア間の関係分類を扱う。このタス クにおいては, 文の依存構造情報の利用が有用であることが知られている (Culotta and Sorensen 2004). 特に, 依存木上のエンティティペア間を繋ぐ最短経路内に存在するトークンのみを関係 分類モデルの入力にするヒューリスティックを用いることで, さらなる識別性能の向上が報告 されている (Bunescu and Mooney 2005). この手法は，エンティティペア間の関係についての 言及は依存構造木上でそのペア間を繋ぐ最短経路上に大抵の場合存在するという観察結果に基 づいている。 この手法によって，入力文が非常に長い場合や，エンティティペアの間に多くの トークンが含まれるような場合であっても，そのうち構文的にエンティティペアを直接繋げる 比較的少量のトークンのみを抜き出すことができる.

最短経路のヒューリスティックは, 元々 Support Vector Machine (SVM) による特徵量ベー スの関係分類モデルにおいて提案されていたが, ニューラルネットワークによるニューラル関 係分類モデルにおいても有効であることが報告されている $(\mathrm{Xu}, \mathrm{Mou}, \mathrm{Li}, \mathrm{Chen}, \mathrm{Peng}$, and Jin 2015; Xu, Jia, Mou, Li, Chen, Lu, and Jin 2016; Miwa and Bansal 2016). しかしながら，関係 についての言及は常に最短経路上にのみ存在するわけではなく，そのような例外のケースでは 最短経路上の情報のみを入力とするのは不十分である。例えば図 1 の cable と insulation 間の関 係分類を行うときを考えると, 所有格の $s$ は最短経路上には含まれず，最短経路上のトークン のみから関係分類を行う場合, 関係の向きが不明瞭になってしまう.

Component-Whole（部品の関係）

入力文 : A portion of the Ethernet $\underset{\mathrm{eable}}{\mathrm{c} 1}$ 's outer $\underset{\mathrm{e} 2}{\text { insulation }}$ is in the connector as well.

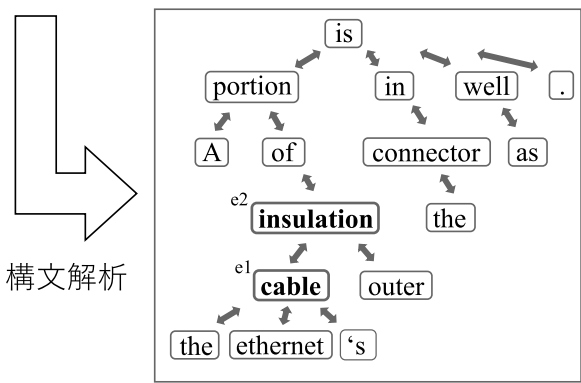

依存構造

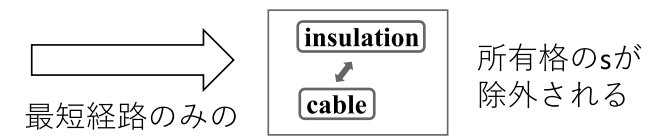

取り出し
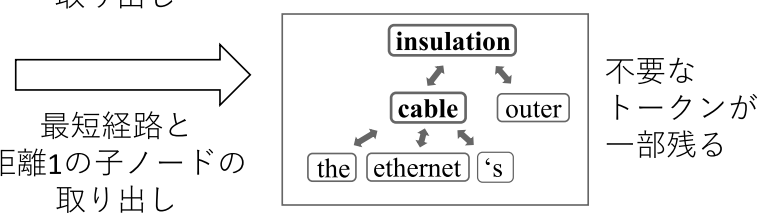

図 1 最短経路やその子ノードを含む部分木を取り出すヒューリスティックの例. 注目エンティティペア を $\mathrm{e} 1$ と2 で示した. 
Zhang らは Graph Convolutional Network (GCN) で依存木を用いて計算を行う際，最短経路 上のトークンのみではなく，最短経路上のトークンから数ステップの距離にある子トークンも 含めた部分木を利用することで，木全体や最短経路上のトークンのみを利用する場合よりも性 能向上を達成できる手法を提案した (Zhang, Qi, and Manning 2018).この手法で距離 1 まで のトークンを利用する場合，図 1 における所有格の $s$ を含めることができる。しかし， the や ethernet といった関係分類に不要なトークンも含めてしまうため, さらに良い選択規則が存在 することを示唆している.

本研究では，関係分類の識別性能の向上を目指し，ニューラルネットワークによる重要トー クンの判別を行うマスク機構と，それを用いたニューラル関係分類モデルを提案する。この提 案機構では, ヒューリスティックの代わりに，学習を通じて重要トークンの判別規則を獲得す る。学習は関係分類のタスク損失から End-to-Endに行われ，追加のアノテーションの必要はな い. マスク機構の訓練では Gumbel トリックを用いたサンプリング (Jang, Gu, and Poole 2017) を行うことで, 離散的なトークンの選択処理を自然に表現する. 加えて, 訓練中はマスク機構 内にノイズを加えることで，マスクされるトークンの量をコントロールする，さらに，アテン ション機構を用いることでマスクされた入力を元に計算された表現を集約する。提案モデルは 再帰型／木構造ニューラルネットワークによる関係分類モデルである LSTM-ER モデル (Miwa and Bansal 2016) をべースに, 提案機構を導入する形で構築する。実験では提案モデルと, 提 案機構を導入せず代わりに依存木全体やヒューリスティックによる部分木を用いたモデルと比 較することで，提案手法の有効性を確認した.

本研究の貢献は以下の三つである.

(1) 最短経路のヒューリスティックを用いる代わりに, 学習から重要なトークンの判別規則を 学習するマスク機構を提案した。 マスク機構は Gumbelトリックを用いることで訓練可 能な離散的なマスクを表現し, 追加のアノテーションなしにタスク損失から End-to-End に学習が可能である.

(2) 提案機構を導入した関係分類モデルにより, 最短経路のヒューリスティックを上回る性能 を得た。また依存木全体を用いるベースラインモデルに対し有意な性能向上を達成した。

(3) 提案機構により学習されたマスクと最短経路のヒューリスティックの類似度について調 査した，学習されたマスクは最短経路と高い類似度となった一方, 異なる学習試行ごと のマスク間の類似度はさらに高く，最短経路と一部異なる判別規則を学習していること を確認した。 


\section{2 関連研究}

\section{1 関係分類}

関係分類とは，文書内のエンティティのペア間について，その文書内の言及に基づいた関係を 分類するタスクである。例えば, “The doctor implanted an injection into three vertical glabellar furrows.”という文中の, injection とfurrows というエンティティペアに注目したとき, injection を furrowsに注射したとの言及から，この二者間には一方をもう一方の位置に移したという“移 動物とその移動先の関係”が成立していると分類する。候補となる関係クラスセットのうちの どれ一つも成立していない場合, 負例クラスを割り当てる.

一文内に同時に出現しているエンティティペア間からの関係分類では, 依存構造木の利用が 有効であることが知られている (Culotta and Sorensen 2004). 特に, この設定においてエンティ ティペア間の関係について言及している箇所は, 依存構造木におけるエンティティペアを繋ぐ最 短経路のパス上に存在することが多いという観察結果がある。この観察結果に基づき, 最短経路 上に存在するトークンのみによる情報を関係分類モデルの入力とすることで関係分類に不要な 情報を除去し, 識別性能の向上を達成する手法が報告されている (Bunescu and Mooney 2005). この最短経路のヒューリスティックでは，入力文が非常に長い場合や，エンティティペアの間 に多くのトークンが含まれるような場合であっても，そのうち構文的にエンティティペアを直 接繋げる比較的少量のトークンのみを抜き出すことができる.

最短経路のみを利用するヒューリスティックは，もともとは特徵量ベースのシステムで提案 されたものであるが, 近年のニューラル関係分類モデルにおいても有効性が確認されている $(\mathrm{Xu}$ et al. 2015, 2016; Miwa and Bansal 2016). Xu らは依存木上の最短経路パスを最近共通祖先ノー ドで分割し，それぞれを系列 Long Short-Term Memory (LSTM) を用いてエンコードすること で構文情報を利用する SDP-LSTM モデルを提案した (Xu et al. 2015).ささらにXuらは, LSTM の代わりに多層再帰型ニューラルネットワークを用いたDRNNs モデルを提案しており，関係 ラベルの向きを逆転させた事例の利用とあわせることでさらなる性能向上を達成している $(\mathrm{Xu}$ et al. 2016). これらの二つのモデルでは, 各単語の WordNet 情報 (Fellbaum 1998)の埋め込み が入力に利用されている。 三輪らは系列 LSTM と木構造 LSTM をスタックすることで系列情 報と依存木情報を共に利用する LSTM-ER モデルを提案した (Miwa and Bansal 2016)，このモ デルにおいて，依存木全体ではなく最短経路上のトークンのみからなる部分木を利用すること により性能が向上すると報告している。また，WordNet 埋め达みの利用により，さらなる性能 向上が報告されている。

最短経路のヒューリスティックの有効性が報告されている一方で, not や into, 所有格の $s$ な ど, 一部の関係分類に有用な単語には最短経路外に存在してしまうものがある。Zhang らは最 短経路外の重要なトークンを利用しつつ, 不要なトークンは最大限除去するために, 最短経路 
上のトークンから特定の距離内の子トークンも利用するヒューリスティックを提案した (Zhang et al. 2018). 実験では, このヒューリスティックの距離 1, すなわち最短経路上の各トークン とそれらの直接の子トークンを利用する設定を用いることで，GCN ベースの関係分類モデルの 識別性能を，最短経路のヒューリスティックを用いる場合よりもさらに向上できると報告され ている。しかしながらこのヒューリスティックでは, 図 1 における the や ethernet など, 最短 経路外に存在する不要な情報を入力に含めてしまうという問題がある。また, このヒューリス ティックは最短経路上のトークンの子孫のみを追加する手法であり，エンティティペアの最近 共通祖先より上の祖先などについては利用しない.

Shen らは畳み込みニューラルネットワークを用いた関係抽出モデルによって, 依存構造木を 用いることなく高い識別性能を達成した (Shen and Huang 2016). このモデルはアテンション 機構を利用しており，重要な情報を持つ単語への重み付けを自動で学習する。

近年，大規模コーパスによる事前学習済み言語モデルが，様々な自然言語処理タスクにおい て高い転移性能を記録している (Peters, Neumann, Iyyer, Gardner, Clark, Lee, and Zettlemoyer 2018; Devlin, Chang, Lee, and Toutanova 2019). そのうちの一つである BERT モデルは, 文中 のマスクされたトークンを予測する穴埋め問題と, 隣接文推定によって双方向言語モデルを学習 する (Devlin et al. 2019). 事前学習済み BERT モデルを用いた関係分類モデルである BERT $\mathrm{EM}_{\mathrm{EM}}$ モデルは，入力文中にエンティティの位置を示す特殊なトークンを挿入することで，複数の関 係分類タスクにおいて既存手法を上回る識別性能を達成した (Baldini Soares, FitzGerald, Ling, and Kwiatkowski 2019).

\subsection{Gumbel トリック}

Jang らは, Gumbelトリックと呼ばれる, 離散的な確率変数の勾配計算のための, 任意のカテ ゴリカル分布に基づいた確率分布のサンプリング手法を提案した (Jang et al. 2017). この手法 によってサンプリングされる確率分布は，その分布中で最大の確率となるクラスの分布が元の カテゴリカル分布と同じになる。また, サンプリングされる確率值は, 温度パラメータによっ て 0 か 1 に近付くよjにコントロールでき，低い温度に設定することによって（ほとんど）離 散的なサンプリングを実現できる. さらに，このサンプリングされた分布は元のカテゴリカル 分布の值について連続であるため, このサンプリング手法をニューラルネットワークモデル内 に組み込むことで，カテゴリカル分布の計算に用いたパラメータを勾配法によって学習でき, ネットワーク内で離散的な挙動を行う機構を自然に表現できる. 


\section{3 提案手法}

本稿では不要な箇所の判別法を自動で学習し遮断するマスク機構を備えたニューラル関係分 類モデルを提案する。提案モデルの概観を図 2 に示す。マスク機構は注目エンティティペア間 の関係分類を行うにあたり不要なトークンの表現ベクトルを 0 ベクトルにマスクし，続く木構 造 LSTM 層にはこのマスク後のベクトル列を入力として計算を行う．木構造 LSTM からの出 力はアテンション機構によって集約され，その後の隠れ層へと入力される.

本章では, 初めに本研究におけるべースラインモデルの説明を行う。続いて, 提案手法とな るマスク機構と, その機構内でマスク量を増進するために行うノイズの加算について説明する. 次に, 木構造 LSTM 層からの出力を集約するアテンション機構の構造について述べる. 最後に, 提案機構を導入した関係分類モデルの全体像について述べる.

\section{1 ベースラインモデル}

本研究ではベースラインモデルとして系列 LSTM と木構造 LSTM をスタックしたニューラ ル関係分類モデルを用いた。 このモデルは三輪らの LSTM-ER モデル (Miwa and Bansal 2016) を基としており，単語列とそれぞれの品詞，およびその単語列のうちの注目しているエンティ ティペアの位置を受け取り，その注目ペア間に成立する関係について，各クラスごとの予測確 率を出力する。 このモデルは入力層, 系列 LSTM 層, 木構造 LSTM 層, 隠れ層, 出力層の五つ の層から構成される。

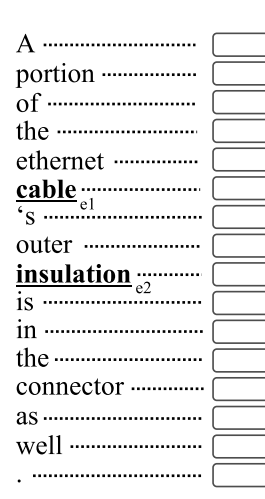

入力 入力層

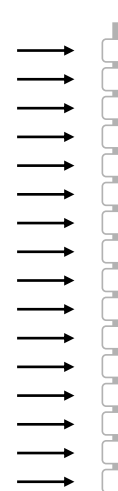

STM層

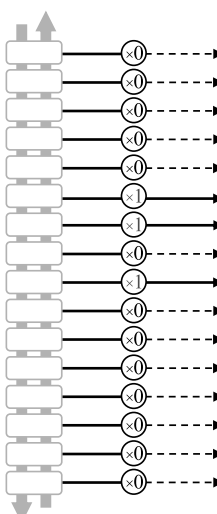

マスク機構

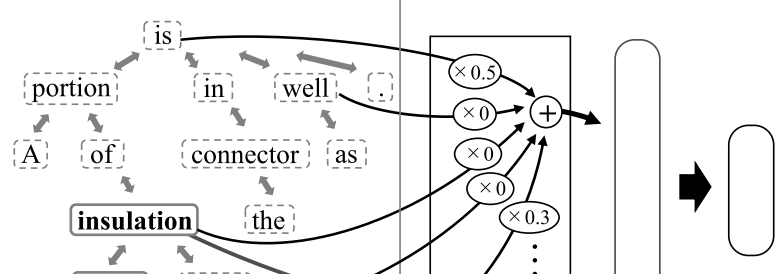

the ethernet

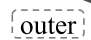

is
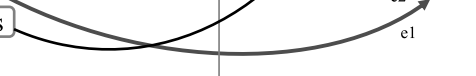

アテンション 隠れ層 出力層

図 2 提案モデルの概観. 注目エンティティペアを $\mathrm{e} 1$ と 2 ででした 


\subsection{1 入力層}

入力層では入力系列の各トークンの単語の埋め込みベクトルと品詞の埋め込みベクトルを連 結し，それぞれの単語べクトルとする，入力中の $i$ 番目のトークンの単語ベクトル $\boldsymbol{v}_{i}^{\text {in }}$ は, その 単語を $w_{i}$, 品詞を $s_{i}$ としたとき以下から得る.

$$
\boldsymbol{v}_{i}^{\text {in }}=\left[\operatorname{Lookup}\left(W^{\text {word }}, w_{i}\right) ; \operatorname{Lookup}\left(W^{\mathrm{POS}}, s_{i}\right)\right],
$$

ここで $W^{\text {word }}$ と $W^{\mathrm{POS}}$ はそれぞれ単語と品詞の埋め込み行列で, 行数はそれぞれ $d^{W}$ 行と $d^{P}$ 行である. Lookup は行列中の対応する列べクトルを返す関数である. $[\boldsymbol{a} ; \boldsymbol{b}]$ はベクトル $\boldsymbol{a}$ と $\boldsymbol{b}$ の列方向での連結を表す.

\subsection{2 系列 LSTM 層}

系列 LSTM 層では単語ベクトルを双方向系列 LSTM に入力し, 文脈を考慮した単語ベクトルと する.この層で用いる系列 LSTM としては, peephole 結合 (Gers, Schraudolph, and Schmidhuber 2002) を備えた構造のものを利用する.

入力文の系列長を $n^{s}$ としたとき, 順方向の系列 LSTM の出力 $\boldsymbol{v}_{1}^{\rightarrow}, \ldots, \boldsymbol{v}_{n^{s}}$ は以下の式より得る.

$$
\begin{aligned}
& \boldsymbol{g}_{i} \vec{t}=\tanh \left(W^{f g}\left[\boldsymbol{v}_{i}^{\text {in }} ; \boldsymbol{v}_{i-1}\right]+\boldsymbol{b}^{f g}\right) \\
& \boldsymbol{i}_{i} \vec{i}=\sigma\left(W^{f i}\left[\boldsymbol{v}_{i}^{\text {in }} ; \boldsymbol{v}_{i-1}\right]+\boldsymbol{w}^{f i} \odot \overrightarrow{\boldsymbol{c}_{i-1}}+\boldsymbol{b}^{f i}\right) \\
& \boldsymbol{f}_{i}^{\rightarrow}=\sigma\left(W^{f f}\left[\boldsymbol{v}_{i}^{\text {in }} ; \boldsymbol{v}_{i-1}\right]+\boldsymbol{w}^{f f} \odot \overrightarrow{\boldsymbol{c}_{i-1}}+\boldsymbol{b}^{f f}\right)
\end{aligned}
$$

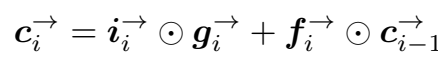

$$
\begin{aligned}
& \overrightarrow{\boldsymbol{o}_{i}}=\sigma\left(W^{f o}\left[\boldsymbol{v}_{i}^{\text {in }} ; \boldsymbol{v}_{i-1}\right]+\boldsymbol{w}^{f o} \odot \overrightarrow{\boldsymbol{c}_{i}}+\boldsymbol{b}^{f o}\right) \\
& \boldsymbol{v}_{i} \overrightarrow{ }=\overrightarrow{\boldsymbol{o}_{i}} \odot \tanh \left(\boldsymbol{c}_{i}\right),
\end{aligned}
$$

出力 $\boldsymbol{v}_{i} \rightarrow$ の次元数を $d^{\mathrm{cseq}}$ とする. $W^{f g}, W^{f i}, W^{f f}, W^{f o}$ はそれぞれ $d^{\mathrm{cseq}} \times\left(d^{W}+d^{P}+d^{\mathrm{cseq}}\right)$ 次 元の重み行列で, $\boldsymbol{w}^{f i}, \boldsymbol{w}^{f f}, \boldsymbol{w}^{f o}$ は $d^{\mathrm{cseq}}$ 次元の重みべクトル, $\boldsymbol{b}^{f g}, \boldsymbol{b}^{f i}, \boldsymbol{b}^{f f}, \boldsymbol{b}^{f o}$ は $d^{\mathrm{cseq}}$ 次元の バイアスである。 ○はアダマール積で, $\sigma$ はシグモイド関数である. 初期状態 $\boldsymbol{c}_{0}, \boldsymbol{v}_{0} \rightarrow$ にはゼロ ベクトルを用いる．逆方向の系列 LSTM の出力 $\boldsymbol{v}_{1}^{\leftarrow}, \ldots, \boldsymbol{v}_{n^{s}}^{\leftarrow}$ は入力文の末尾から逆順で処理する ことにより得る。重みとバイアスは各方向ごとに別個に用意する.

この双方向系列 LSTM の出力に, 入力文の依存木における親トークンへの係り受け $t_{i}$ の埋め 込みベクトルと, 注目エンティティペアそれぞれからの相対距離の埋め込みベクトルを連結し, これを系列 LSTM 層の出力 $\boldsymbol{v}_{1}^{\mathrm{seq}}, \ldots, \boldsymbol{v}_{n^{s}}^{\mathrm{seq}}$ とする.

$$
\begin{aligned}
\boldsymbol{v}_{i}^{\text {dep }} & =\operatorname{Lookup}\left(W^{\text {dep }}, t_{i}\right) \\
\boldsymbol{v}_{j}^{\text {rpos }} & =\operatorname{Lookup}\left(W^{\text {rpos }}, \operatorname{Clip}(j,-P, P)\right)
\end{aligned}
$$




$$
\boldsymbol{v}_{i}^{\mathrm{seq}}=\left[\boldsymbol{v}_{i}^{\rightarrow} ; \boldsymbol{v}_{i}^{\leftarrow} ; \boldsymbol{v}_{i}^{\mathrm{dep}} ; \boldsymbol{v}_{i-\mathrm{e} 1}^{\mathrm{rpos}} ; \boldsymbol{v}_{i-\mathrm{e} 2}^{\mathrm{rpos}}\right]
$$

ここで $W^{\text {dep }}$ は係り受けの埋め达み行列で, 行数は $d^{D}$ 行である. $W^{\text {rpos }}$ はエンティティからの 相対距離の埋め込み行列であり, 各列べクトル $\boldsymbol{v}_{j}^{\mathrm{rpos}}$ の次元数は $d^{R}$ である. e1 と e2 は注目工 ンティティペアのそれぞれのインデックスを表す. $\operatorname{Clip}(a, b, c)$ は值 $a$ を最小 $b$, 最大 $c$ の範囲に 収まるようにクリッピングする関数であり，Pは相対距離のウインドウサイズを表すハイパー パラメータである。

\subsection{3 木構造 LSTM 層}

木構造 LSTM 層では, 系列 LSTM 層の出力を入力として, 入力文の依存木に基いて木構造 LSTM の計算を行う。この層では上向きと下向きの各方向について依存木を走査する, 双方向木 構造 LSTM を用いる，木構造 LSTM の実装には，メモリの追加分 $\boldsymbol{g}_{i}^{\uparrow}$ や入力, 出力ゲート $\boldsymbol{i}_{i}^{\uparrow}, \boldsymbol{o}_{i}^{\uparrow}$ を前状態群の単純な合計から計算する Child-Sum 木構造 LSTM (Tai, Socher, and Manning 2015) を用いる。上向き木構造 LSTM の計算は以下となる.

$$
\begin{aligned}
\boldsymbol{g}_{i}^{\uparrow} & =\tanh \left(W^{u g x} \boldsymbol{v}_{i}^{\text {seq }}+\sum_{j \in \operatorname{Child}(i)} W^{u g h} \boldsymbol{v}_{j}^{\uparrow}+\boldsymbol{b}^{u g}\right) \\
\boldsymbol{i}_{i}^{\uparrow} & =\sigma\left(W^{u i x} \boldsymbol{v}_{i}^{\text {seq }}+\sum_{j \in \operatorname{Child}(i)} W^{u i h} \boldsymbol{v}_{j}^{\uparrow}+\boldsymbol{b}^{u i}\right) \\
\boldsymbol{f}_{i j}^{\uparrow} & =\sigma\left(W^{u f x} \boldsymbol{v}_{i}^{\text {seq }}+W^{u f h} \boldsymbol{v}_{j}^{\uparrow}+\boldsymbol{b}^{u f}\right) \quad \text { for } j \in \operatorname{Child}(i) \\
\boldsymbol{c}_{i}^{\uparrow} & =\boldsymbol{i}_{i}^{\uparrow} \odot \boldsymbol{g}_{i}^{\uparrow}+\sum_{j \in \operatorname{Child}(i)} \boldsymbol{f}_{i j}^{\uparrow} \odot \boldsymbol{c}_{j}^{\uparrow} \\
\boldsymbol{o}_{i}^{\uparrow} & =\sigma\left(W^{u o x} \boldsymbol{v}_{i}^{\text {seq }}+\sum_{j \in \operatorname{Child}(i)} W^{u o h} \boldsymbol{v}_{j}^{\uparrow}+\boldsymbol{b}^{u o}\right) \\
\boldsymbol{v}_{i}^{\uparrow} & =\boldsymbol{o}_{i}^{\uparrow} \odot \tanh \left(\boldsymbol{c}_{i}^{\uparrow}\right),
\end{aligned}
$$

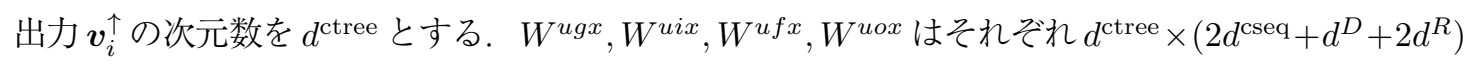
次元の重み行列で, $W^{u g h}, W^{u i h}, W^{u f h}, W^{u o h}$ はそれぞれ $d^{\text {ctree }} \times d^{\text {ctree }}$ 次元の重み行列である. $\boldsymbol{b}^{u g}, \boldsymbol{b}^{u i}, \boldsymbol{b}^{u f}, \boldsymbol{b}^{u o}$ は $d^{\text {ctree }}$ 次元のバイアスである. Child $(a)$ はノード $a$ の子ノードの集合を表す 関数である. 下向き木構造 LSTM の出力 $\boldsymbol{v}_{1}^{\downarrow}, \ldots, \boldsymbol{v}_{n^{s}}^{\downarrow}$ は別個に重みとバイアスを用意し, 子ノード の代わりに親ノードを前の状態に用いることで計算する，親ノードは常に高々一つしか存在し ないので, 下向き木構造 LSTM は peephole のない系列 LSTM とほとんど同様の計算式になる.

木構造 LSTM 層の出力 $\boldsymbol{v}^{\text {tree }}$ は, 上向き木構造 LSTM における, 依存木上で根ノードにあた るトークンの出力ベクトルと, 下向き木構造 LSTM における注目エンティティペアの各出力ベ クトルを連結したベクトルであり，これを続く隠れ層へ入力する. 


$$
\boldsymbol{v}^{\text {tree }}=\left[\boldsymbol{v}_{\text {root }}^{\uparrow} ; \boldsymbol{v}_{\mathrm{e} 1}^{\downarrow} ; \boldsymbol{v}_{\mathrm{e} 2}^{\downarrow}\right],
$$

rootは根ノードのトークンのインデックスを表す.

\subsection{4 隠れ層・出力層}

隠れ層は全結合層と $\tanh$ 関数による活性化で構成される。この層では木構造 LSTM 層の出 力を入力として隠れベクトル $h$ を得る.

$$
\boldsymbol{h}=\tanh \left(W^{h} \boldsymbol{v}^{\text {tree }}+\boldsymbol{b}^{h}\right),
$$

ここで $W^{h}$ と $\boldsymbol{b}^{h}$ はそれぞれ重み行列とバイアスである，この隠れベクトルは出力層に入力さ れ，ソフトマックス関数を適用することにより最終的な関係クラス $c$ ごとの予測確率 $p_{c}$ を得る.

$$
p_{c}=\frac{\exp \left(\boldsymbol{w}_{c}^{o \top} \boldsymbol{h}+b_{c}^{o}\right)}{\sum_{i} \exp \left(\boldsymbol{w}_{i}^{o \top} \boldsymbol{h}+b_{i}^{o}\right)},
$$

ここで $\boldsymbol{w}_{c}^{o}$ と $b_{c}^{o}$ はそれぞれ関係クラス $c$ ごとの重みベクトルとバイアスである.

\subsection{5ＬSTM-ER モデルとの相違点}

ベースラインモデルは LSTM-ER モデルとほとんど同じ構造であるが，主に以下の三つの点 で異なる。一つ目の相違点は木構造 LSTM の計算である，LSTM-ER モデルでは最短経路かそ うでないかによって利用する行列を変え，また各子ノードに対する忘却ゲートの計算に他の兄 弟ノードを利用する，SPTree と呼ばれる木構造 LSTM (Miwa and Bansal 2016) を用いるが，本 研究のベースラインモデルには Child-Sum 木構造 LSTM (Tai et al. 2015) を用いる. これは, 我々の目的が最短経路のヒューリスティックの利用からの脱却を目指しているからである。ま た, Child-Sum 木構造 LSTM はその計算式の単純さから並列化が容易であるというメリットもあ る。二目に, ベースラインモデルでは全層でドロップアウト (Srivastava, Hinton, Krizhevsky, Sutskever, and Salakhutdinov 2014) を利用するようにする。ドロップアウト率は開発データで チューニングを行い決定する。三つ目の違いとして，LSTM-ER モデルでは木構造 LSTM 層を スキップして系列 LSTM の出力を直接隠れ層へ入力する, Pair と呼ばれるコネクションが存在 するが, 本研究ではこれを取り外したモデルを主に用いる。これは, 我々の提案手法が木構造 LSTM 層の計算に影響を及ぼす手法であり，提案手法の影響がより直接出力に現れるようにす るためである. Pair コネクションを利用する場合の隠れ層は，元々の入力 $\boldsymbol{v}^{\text {tree }}$ に加えて，エン ティティペアに対応する双方向系列 LSTM の出力を結合したベクトル $\boldsymbol{v}^{\mathrm{pair}}$ を入力とする.

$$
\boldsymbol{v}^{\text {pair }}=\left[\boldsymbol{v}^{\text {tree }} ; \boldsymbol{v}_{\mathrm{e} 1}^{\rightarrow} ; \boldsymbol{v}_{\mathrm{e} 1}^{\leftarrow} ; \boldsymbol{v}_{\mathrm{e} 2} ; \boldsymbol{v}_{\mathrm{e} 2}^{\leftarrow}\right],
$$




\section{2 マスク機構}

関係分類にあたり不要な情報を取り除くマスク機構を提案する。この機構は, ニューラル関係 分類モデルの中間層として働き, 注目しているエンティティペアの関係について無関係なトー クンを判別し，対応する中間表現を 0 ベクトルにすることで情報を取り除く.

\subsection{1＼cjkstart確信度スコアとマスクの計算}

初めに，この機構は各トークンが注目エンティティペアの関係についての言及であるかどう かの確信度スコアを計算する。この確信度は高ければ高いほど関係についての言及であると判 断したことを表す。 $i$ 番目のトークンの確信度スコア $c_{i}$ を以下の式で計算する.

$$
\begin{aligned}
\boldsymbol{v}^{m q} & =\frac{\boldsymbol{v}_{\mathrm{e} 1}^{\mathrm{seq}}+\boldsymbol{v}_{\mathrm{e} 2}^{\mathrm{seq}}}{2} \\
\boldsymbol{h}^{m q} & =\operatorname{Normalize}\left(W^{m q} \boldsymbol{v}^{m q}\right) \\
\boldsymbol{h}^{m k} & =\operatorname{Normalize}\left(W^{m k} \boldsymbol{v}_{i}^{\mathrm{seq}}\right) \\
c_{i} & =\sigma\left(\frac{\boldsymbol{h}^{m q^{\top}} \boldsymbol{h}^{m k}}{\sqrt{d^{m}}}\right),
\end{aligned}
$$

ここで $\boldsymbol{v}_{i}^{\mathrm{seq}}$ は式 (3) の系列 LSTM 層からの $i$ 番目のトークンの出力である. $W^{m q}$ と $W^{m k}$ は $d^{m} \times\left(2 d^{\mathrm{cseq}}+d^{D}+2 d^{R}\right)$ 次元の重み行列で, $d^{m}$ はマスク機構の隠れベクトルの次元数である. Normalize は与えられたベクトルが平均 0 , 分散 1 になるように正規化する関数である.

$$
\begin{aligned}
\operatorname{mean}(\boldsymbol{v}) & =\frac{1}{\operatorname{dim}(\boldsymbol{v})} \sum_{i} v_{i} \\
\operatorname{stddev}(\boldsymbol{v}) & =\sqrt{\frac{1}{\operatorname{dim}(\boldsymbol{v})} \sum_{i}\left(v_{i}-\operatorname{mean}(\boldsymbol{v})\right)^{2}} \\
\operatorname{Normalize}(\boldsymbol{v}) & =\frac{\boldsymbol{v}-\operatorname{mean}(\boldsymbol{v})}{\operatorname{stddev}(\boldsymbol{v})},
\end{aligned}
$$

$\operatorname{dim}(\boldsymbol{v})$ はベクトル $\boldsymbol{v}$ の次元数である。この確信度スコア $c_{i}$ の, 各トークンの表現ベクトルを 用いた内積を, その次元数の正の平方根で除する計算は, Vaswawni らによるアテンション機構 (Vaswani, Shazeer, Parmar, Uszkoreit, Jones, Gomez, Kaiser, and Polosukhin 2017) の計算式を 参考にしている. 式 (9) 中の $\boldsymbol{v}^{m q}$ は, エンティティペアの関係を言及するような重要なトークン を判定するためのクエリの役割を果たす，エンティティペアの関係を言及するトークンは，ペ アの順序に依存しないと考えられるので， $\boldsymbol{v}^{m q}$ はペアの順序に依存しにくくなるようペアに対 応する系列 LSTM 層の出力 $\boldsymbol{v}_{\mathrm{e} 1}^{\mathrm{seq}}, \boldsymbol{v}_{\mathrm{e} 2}^{\mathrm{seq}}$ の平均の形で計算することとした，ただし式 (3) の通り, 各 $\boldsymbol{v}_{i}^{\mathrm{seq}}$ 自体に両エンティティからの相対距離の埋め込みベクトルが順序依存で連結されている ため, エンティティペアの順序の入れ替えについて完全なロバストではない. 
訓練時は得られた $c_{i}$ に基づき, Gumbel トリック (Jang et al. 2017) を用いてほとんど 0 か 1 に近い值になるマスク $m_{i}$ をサンプリングする.

$$
\begin{aligned}
u_{c_{i}}^{(0)}, u_{c_{i}}^{(1)} & \sim \operatorname{Uniform}(0,1) \\
x_{c_{i}}^{(1)} & =c_{i} \\
x_{c_{i}}^{(0)} & =1-c_{i} \\
l_{c_{i}}^{(k)} & =\frac{\log \left(x_{c_{i}}^{(k)}\right)-\log \left(-\log \left(u_{c_{i}}^{(k)}\right)\right)}{\tau} \quad \text { for } \mathrm{k} \in\{0,1\} \\
m_{i} & =\frac{\exp \left(l_{c_{i}}^{(1)}\right)}{\exp \left(l_{c_{i}}^{(0)}\right)+\exp \left(l_{c_{i}}^{(1)}\right)},
\end{aligned}
$$

ここで $\tau$ は温度パラメータであり，学習せず訓練の進行に合わせて少しずつ小さくする。これ によって得られるマスク $m_{i}$ は, 確信度スコア $c_{i}$ が高いほど 1 に近い值を, 確信度が低いほど 0 に近い值をとる頻度が高くなる。また， $c_{i}$ について連続であるため， $c_{i}$ の計算に用いられた 重みを勾配法によって学習すること可能である. このマスクを系列 LSTM の出力に乗じること によってモデルが不要と判断した情報を取り除いたべクトル列を獲得し，それを木構造 LSTM への入力とする.

\subsection{2 ノイズによるマスク量の増進}

系列 LSTM 層の出力へのマスクの乗算により, 不要なトークンに対する確信度が低い值にな るように学習されれば，不要な情報の削減は実現される。しかしながら実際にこのまま適用す ると，学習される確信度の值はほとんど 1 となり，ほとんどマスクされずに木構造 LSTMへ入 力されてしまう。そこで, モデルの訓練時, 入力にマスク量に応じたノイズを加えることによっ てマスクされるトークン数を増進し, この問題を解決する.

初めに, 文中の各トークンに対する確信度の平均值としてその文のトークンの生存率 $r$ を計 算する.

$$
r=\frac{\sum_{i=1}^{n^{s}} c_{i}}{n^{s}},
$$

次に, 系列 LSTM からの出力と同じ次元の正規分布 $\mathcal{N}(\mathbf{0}, \boldsymbol{I})$ からサンプリングしたベクトル $\boldsymbol{p}_{i}$ に，この生存率 $r$ とノイズの係数パラメータ $\alpha$ を乗じることでノイズを計算する。 これは，各 次元の分布が平均 0 , 分散 $\alpha^{2} r^{2}$ であるようなノイズをサンプリングしていると捉えることもで きる，そしてこのノイズを系列 LSTM の出力に加えた後にマスクを行うことで最終的なマスク 後の出力を得る. 訓練時のマスク機構からの $i$ 番目のトークンの出力 $\boldsymbol{v}_{i}^{m}$ は以下となる.

$$
\boldsymbol{v}_{i}^{m}=m_{i}\left(\boldsymbol{v}_{i}^{\mathrm{seq}}+\alpha r \boldsymbol{p}_{i}\right)
$$


係数パラメータ $\alpha$ は開発データに扔ける識別性能からチューニングして決定する，学習ではノ イズによる損失の増加を抑えるためにノイズの係数となる生存率を下げるようにパラメータが 動き，それによってマスクされるトークン数が増えることを期待する。

このノイズを加えるという処理は次のような考えに基づいている．入力文内には注目エンティ ティペア間の関係について無関倸な言及も含まれるが，その無関係な情報の利用は関係分類モ デルにとってノイズになる。これを，マスク機構においてマスクされなかったトークンが多い ほど大きくなるノイズを加えることで表現し，ノイズを減らすためにマスクされるトークンを 増やすという方向に学習が進むことを期待する.

\subsection{3 テスト時のマスクの適用}

テスト時はノイズを加えず，マスク $m_{i}$ についてもサンプリングを行わず䦨值 0.5 を超えた かどうかにより決定的に計算する。したがってテスト時のマスク機構からの出力 $\boldsymbol{v}_{i}^{m}$ は以下と なる。

$$
\begin{aligned}
& m_{i}= \begin{cases}1, & \text { if } c_{i} \geq 0.5 \\
0, & \text { otherwise. }\end{cases} \\
& \boldsymbol{v}_{i}^{m}=m_{i} \boldsymbol{v}_{i}^{\mathrm{seq}},
\end{aligned}
$$

\section{3 アテンション機構}

ベースラインモデルでは, 上向き木構造 LSTM の出力ベクトル列のうち, 木構造の根トーク ンのベクトルを隠れ層への入力に使用する。しかしながら，マスク機構を用いた場合は根や最 近共通祖先のトークンを含めどのトークンがマスクされるか事前にはわからず，あらかじめ上 向き木構造 LSTM の出力のうち利用するトークンを定めることが難しい. そこで, あらかじめ 特定のトークンを選ぶ代わりに, アテンション機構を用いて上向き木構造 LSTM の出力ベクト ル列を集約し，これを木構造 LSTM 層の出力の一部として用いる。この機構は, Vaswawni ら によるアテンション機構 (Vaswani et al. 2017) を参考に, 各トークンの表現ベクトルの内積を その次元数の正の平方根で除してアテンションのスコアを計算し，これを異なるパラメータで 複数用意して並列させる構造になっている.

初めに，集約対象を指示するクエリベクトル $\boldsymbol{v}^{a q}$ を, 3.1 .3 節のエンティティペアの双方向木 構造 LSTM の出力の合計と差の連結として構成する. 差については 1 次元目の值が常に非負の 值となるように，必要に応じて全体の符号を反転させる.

$$
\begin{aligned}
\boldsymbol{v}_{i}^{\uparrow \downarrow} & =\left[\boldsymbol{v}_{i}^{\uparrow} ; \boldsymbol{v}_{i}^{\downarrow}\right] \\
\boldsymbol{q}^{\varsigma} & =\frac{\boldsymbol{v}_{\mathrm{e} 1}^{\uparrow \downarrow}+\boldsymbol{v}_{\mathrm{e} 2}^{\uparrow \downarrow}}{\sqrt{2}}
\end{aligned}
$$




$$
\begin{aligned}
\boldsymbol{q}^{d} & =\boldsymbol{v}_{\mathrm{e} 1}^{\uparrow \downarrow}-\boldsymbol{v}_{\mathrm{e} 2}^{\uparrow \downarrow} \\
\boldsymbol{v}^{a q} & =\left[\boldsymbol{q}^{s} ; \operatorname{sign}\left(q_{1}^{d}\right) \boldsymbol{q}^{d}\right],
\end{aligned}
$$

ここで $\operatorname{sign}(\cdot)$ は符号関数で，次の式により計算する.

$$
\operatorname{sign}(x)= \begin{cases}1, & x \geq 0 \\ -1, & \text { otherwise. }\end{cases}
$$

差のベクトルの符号を反転させる処理は，差のベクトルがエンティティの順序に依存しないよ うにする目的で行った。これは，各值の絶対值を取ったべクトル $\operatorname{abs}\left(\boldsymbol{q}^{d}\right)$ を利用する場合と似 ているが，2 次元目以降の值に負の值が出現しうる点で異なる.

続いて，各トークンのキーベクトル $\boldsymbol{v}_{1}^{a k}, \ldots, \boldsymbol{v}_{n^{s}}^{a k}$ ，それぞれのエンティティペアからの相対 距離の埋め込みべクトルの合計及び差と, 対応する双方向木構造 LSTM の出力から計算する.

$$
\begin{aligned}
\boldsymbol{k}_{i}^{s} & =\frac{\boldsymbol{v}_{i-\mathrm{e} 1}^{\mathrm{rpos}}+\boldsymbol{v}_{i-\mathrm{e} 2}^{\mathrm{rpos}}}{\sqrt{2}} \\
\boldsymbol{k}_{i}^{d} & =\boldsymbol{v}_{i-\mathrm{e} 1}^{\mathrm{rpos}}-\boldsymbol{v}_{i-\mathrm{e} 2}^{\mathrm{rpos}} \\
\boldsymbol{v}_{i}^{a k} & =\left[\boldsymbol{v}_{i}^{\uparrow \downarrow} ; \boldsymbol{k}_{i}^{s} ; \operatorname{sign}\left(k_{i 1}^{d}\right) \boldsymbol{k}_{i}^{d}\right],
\end{aligned}
$$

ここで $\boldsymbol{v}_{j}^{\mathrm{rpos}}$ は式 (3) 中と同一の相対距離の埋め込みベクトルである.

そして，得られたクエリ，キーベクトルを用いてアテンションのスコアを計算し，上向き木 構造 LSTM の出力を集約する。この時計算に用いる重み行列を複数セット用意することで，ア テンションを並列させる。それぞれの独立なアテンション機構をへッドと呼ぶ。並列数を $H$ と する. $i$ 番目のトークンに対する $j$ 番目のヘッドにおけるアテンションのスコア $a_{j i}$ と，集約さ れたベクトル $\boldsymbol{v}_{j}^{a}$ は以下の式より計算する.

$$
\begin{aligned}
\boldsymbol{h}_{j}^{a q} & =\operatorname{Normalize}\left(W_{j}^{a q} \boldsymbol{v}^{a q}\right) \\
\boldsymbol{h}_{j i}^{a k} & =\operatorname{Normalize}\left(W_{j}^{a k} \boldsymbol{v}_{i}^{a k}\right) \\
h_{j i}^{a} & =\frac{\boldsymbol{h}_{j}^{a{ }^{\top}} \boldsymbol{h}_{j i}^{a k}}{\sqrt{d^{a}}} \\
a_{j i} & =\frac{\exp \left(h_{j i}^{a}\right)}{\sum_{i} \exp \left(h_{j i}^{a}\right)} \\
\boldsymbol{v}_{j}^{a} & =\sum_{i} a_{j i} W_{j}^{a v} \boldsymbol{v}_{i}^{\uparrow},
\end{aligned}
$$

ここで $W_{j}^{a q}, W_{j}^{a k}, W_{j}^{a v}(j \in[1, H])$ はそれぞれ $d^{a} \times 4 d^{\text {ctree }}$ 次元と $d^{a} \times 2\left(d^{\text {ctree }}+d^{R}\right)$ 次元, $\frac{d^{\text {ctree }}}{H} \times d^{\text {ctree }}$ 次元の重み行列で, $d^{a}$ はアテンション機構の隠れベクトルの次元数である. 
アテンション機構の出力 $\boldsymbol{v}^{a}$ は, 各ヘッドの出力を並列させることで得る.

$$
\boldsymbol{v}^{a}=\left[\boldsymbol{v}_{1}^{a} ; \ldots ; \boldsymbol{v}_{H}^{a}\right]
$$

\section{4 提案機構を導入した関係分類モデルの全体像}

マスク機構とアテンション機構を導入した関係分類モデルは, 図 2 のように, 入力層, 系列 LSTM 層, マスク機構, 木構造 LSTM 層, アテンション機構, 隠れ層, 出力層の七つの構造 によって構成される, 入力層, 系列 LSTM層の計算については, ベースラインモデルと同様で ある。

マスク機構を導入したモデルは, 木構造 LSTM 層の入力に, 系列 LSTM 層の出力 $\boldsymbol{v}_{1}^{\mathrm{seq}}, \ldots, \boldsymbol{v}_{n^{s}}^{\mathrm{seq}}$ の代わりに，マスク機構によってマスクされた出力 $\boldsymbol{v}_{1}^{m}, \ldots, \boldsymbol{v}_{n^{s}}^{m}$ を用いる。訓練時は式 (13) を, テスト時は式 (14) を用いる。 木構造 LSTM 層ではマスクの值に関わらず常に依存木全体に対し て計算を行う。したがって，マスクの值が 0 となったトークンの木構造 LSTM のセルには 0 ベ クトルが入力される.

アテンション機構を導入したモデルにおける隠れ層への入力は, 式 (5) の上向き木構造 LSTM における根トークンの出力ベクトルを, 式 (19)により計算されたアテンション機構の出力 $\boldsymbol{v}^{a}$ で置き換えたべクトル $\boldsymbol{v}^{\text {att }}$ である.

$$
\boldsymbol{v}^{\text {att }}=\left[\boldsymbol{v}^{a} ; \boldsymbol{v}_{\mathrm{e} 1}^{\downarrow} ; \boldsymbol{v}_{\mathrm{e} 2}^{\downarrow}\right]
$$

マスク機構のみを導入し，アテンション機構を導入しない場合の隠れ層への入力は, 依存木全 体を用いる場合のベースラインモデルと同様, 式 (5)の $\boldsymbol{v}^{\text {tree }}$ を用いる.

隠れ層と出力層については, ベースラインモデルと同様の計算を行う.

\section{4 実験・考察}

本章ではベースラインモデルと提案モデルにおける実験と, その結果に対する考察を述べる. 実験ではベースラインモデルと，マスク機構およびアテンション機構を導入したモデルについ てそれぞれ学習を行い，その識別性能を評価した。また，マスク機構における異なるノイズ強 度ごとの生存率の変化を比較し, 学習されるマスクと最短経路のヒューリスティックの類似度 と, 生存するトークンの傾向について調査し, 考察を行った.

本章では初めに実験設定について説明する，次に，各モデルにおける識別性能について述べ る. 続いて，マスク機構におけるノイズの影響について述べる，最後にマスクされるトークン の傾向について述べる。

特に断りのない限り，実験結果と考察はPair コネクションを取り除いたモデルに対するもの である。 


\section{1 実験設定}

ベースラインモデルと，それにマスク機構およびアテンション機構を導入したモデルについ てそれぞれ学習と評価を行った。 ベースラインモデルでは, 木構造 LSTM 層で用いる木構造と して依存木全体, 最短経路の部分木, およびZhang らによる最短経路から距離 1 のノードも利 用する部分木 (Zhang et al. 2018) の三種類についてそれぞれ実験を行った。 また，Pair コネク ションを付け加えたモデルについても学習と評価を行った.

使用するデータセットとしては，一文内のエンティティペア間の関係分類において代表的 なデータセットの一つである SemEval-2010 Task 8 データセット (Hendrickx, Kim, Kozareva, Nakov, Ó Séaghdha, Padó, Pennacchiotti, Romano, and Szpakowicz 2010) を用いた. このデー タセットは 8,000 件の訓練事例と 2,717 件のテスト事例から構成されている。システムには入力 文とその文内の二つのエンティティの位置が与えられ，あらかじめ定義された九種類の正例関 係クラスおよび負例クラスの中から，そのエンティティペア間に成立している関係を予測する. 正例クラスについてはその関係の向きについても予測する必要がある. 本研究では分類モデル の出力クラスとして各正例ごとに順方向と逆方向の二種類をそれぞれ用意し，計 19 クラスの分 類モデルとした．このデータセットには同じ文が繰り返し出現することがなく，各文ごとにエ ンティティ二つの位置と, そのペア間の関係クラスのアノテーションが付与されている. 公式 の評価指標は Macro-F 值である.

SemEval-2010 Task 8 データセットには公式の開発事例群が存在しないため, 訓練事例のうち 全体の $10 \%$ 開発事例として分割し, ハイパーパラメータチューニングに用いた。 また, Stanford parser (Chen and Manning 2014) を用いて各事例のそれぞれの単語の品詞夕グと依存木 1 を得 た，テスト事例の性能評価は，チューニングしたハイパーパラメータを用いて，開発事例を含 めた訓練事例全体で再度学習したモデルで行った。識別性能の比較は Macro-F 值で行い, 各 モデルについて 5 回ずつ訓練と評価を行ってその平均と標準偏差について評価した，実装には Tensorflow 2 を利用した. Pair コネクションを取り除いたモデルのハイパーパラメータのチュー ニングには RoBO(Klein, Falkner, Mansur, and Hutter 2017) を用いた. RoBO によりチューニ ングしたハイパーパラメータは, 各層のドロップアウト率, 学習率, ノイズの係数パラメータで ある. Pair コネクションを取り除いたモデルで用いた各ハイパーパラメータの值を表 1 に示す. Pair コネクションを付け加えたモデルについては, 実験時間の短縮のため, Pair コネクション を取り除いたモデルでチューニングしたハイパーパラメータを元に, 各層のドロップアウト率 を 0 から 0.7 の範囲で 1 パラメータずつ 0.1 刻みで再度チューニングし, 開発事例における識別 性能が最も高くなった值を採用した，元のドロップアウト率を利用する場合のほうが性能が高

\footnotetext{
1 依存構造の表現形式には木の性質を満たす basic dependencies （collapse なし, propagate なし）を使用した.

2 https://www.tensorflow.org/
} 
表 1 Pair コネクションを取り除いたモデルで用いたハイパーパラメータの值

\begin{tabular}{|c|c|c|}
\hline パラメータ名 & 論文中のシンボル & 值 \\
\hline 単語埋め込みの次元数 & $d^{W}$ & 200 次元 \\
\hline 品詞埋め込みの次元数 & $d^{P}$ & 25 次元 \\
\hline 系列 LSTM のユニット数 & $d^{\text {cseq }}$ & 100 次元 \\
\hline 係り受け埋め込みの次元数 & $d^{D}$ & 25 次元 \\
\hline 相対距離埋め込みの次元数 & $d^{R}$ & 15 次元 \\
\hline 相対距離のウィンドウサイズ & $P$ & 15 \\
\hline マスク機構の隠れベクトルの次元数 & $d^{m}$ & 510 次元 \\
\hline 木構造 LSTM のユニット数 & $d^{\text {ctree }}$ & 100 次元 \\
\hline アテンション機構の隠れベクトルの次元数 & $d^{a}$ & 400 次元 \\
\hline アテンションの並列数 & $H$ & 4 \\
\hline 隠れ層の次元数 & $\boldsymbol{h}$ の次元数 & 100 次元 \\
\hline 系列 LSTM 層への入力のドロップアウト率 & & 0.61249952 \\
\hline マスク機構への入力のドロップアウト率 & & 0.40384934 \\
\hline 木構造 LSTM 層への入力のドロップアウト率 & & 0.01551973 \\
\hline 隠れ層への入力のドロップアウト率 & & 0.14296189 \\
\hline 出力層への入力のドロップアウト率 & & 0.45374747 \\
\hline マスク機構のノイズ係数 & $\alpha$ & 0.7447 \\
\hline 学習アルゴリズム & & Adam \\
\hline 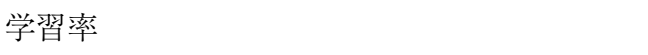 & & $10^{-2.967}$ \\
\hline バッチサイズ & & 32 \\
\hline
\end{tabular}

表 2 Pair コネクションを付け加えたモデルで用いたドロップアウト率のうち, Pair コネクションを取り 除いたモデルと異なる值を採用した箇所とその值

\begin{tabular}{l|c|c}
\hline \multicolumn{1}{c|}{ パラメータ名 } & 新たに採用した值 & 元の值 \\
\hline 木構造 LSTM 層への入力のドロップアウト率 & 0.4 & 0.01551973 \\
隠れ層への入力のドロップアウト率 & 0.5 & 0.14296189 \\
出力層への入力のドロップアウト率 & 0.3 & 0.45374747 \\
\hline
\end{tabular}

くなる場合は，そのままの值を用いた。 Pair コネクションを付け加えた場合と取り除いた場合 で異なるドロップアウト率とした箇所とその值を表 2 に示す.

\section{2 関係の識別性能}

各モデルの Macro-F 值の平均と標準偏差を表 3 に示す。表の通り, Pair コネクションを使わ ない場合, 提案手法を導入したモデルは, マスク機構・アテンション機構共に単独でベースライ ンモデルの識別性能を上回り，両者を併せて導入した場合，さらに識別性能は向上する結果と なった。 マスク機構については，ノイズの係数パラメータ $\alpha$ を 0 にしたノイズを全く利用しない モデルよりも，ノイズを利用するモデルのほうが識別性能が高い結果となった。また，マスク機 
表 3 SemEval-2010 Task 8 における各モデルの Macro-F 值の平均と標準偏差

\begin{tabular}{|c|c|c|}
\hline \multirow{2}{*}{ モデル名 } & \multicolumn{2}{|c|}{ Macro-F 值 (\%) } \\
\hline & 開発事例 & テスト事例 \\
\hline ベースライン & $81.43 \pm 0.28$ & $83.17 \pm 0.16$ \\
\hline + Pair & $82.24 \pm 0.30$ & $83.46 \pm 0.30$ \\
\hline +マスク機構 $(\alpha=0)$ & $82.27 \pm 0.39$ & - \\
\hline +マスク機構 $(\alpha=0.7447)$ & $82.89 \pm 0.13$ & $83.53 \pm 0.29$ \\
\hline +アテンション機構 & $82.84 \pm 0.64$ & $82.95 \pm 0.43$ \\
\hline +マスク機構 $(\alpha=0.7447)+$ アテンション機構 & $83.98 \pm 0.65$ & $83.89 \pm 0.64$ \\
\hline +マスク機構 $(\alpha=0.7447)+$ +アテンション機構 + Pair & $82.89 \pm 0.44$ & $83.20 \pm 0.29$ \\
\hline + 最短経路 & $82.87 \pm 0.52$ & $82.99 \pm 0.46$ \\
\hline +最短経路 + Pair & $83.43 \pm 0.52$ & $84.08 \pm 0.30$ \\
\hline + Zhang らによる距離 1 の部分木 & $83.21 \pm 0.47$ & $83.24 \pm 0.14$ \\
\hline + Zhang らによる距離 1 の部分木 + Pair & $82.46 \pm 0.35$ & $83.88 \pm 0.13$ \\
\hline LSTM-ER （Child-Sum, Pair, 最短経路）（Miwa and Bansal 2016) & 83.8 & - \\
\hline LSTM-ER （SPTree, Pair, 最短経路）（Miwa and Bansal 2016) & 85.1 & 84.4 \\
\hline $\begin{array}{l}\text { LSTM-ER （SPTree, Pair, 最短経路, WordNet） } \\
\text { (Miwa and Bansal 2016) }\end{array}$ & 85.4 & 85.5 \\
\hline Attention-CNN （依存構造なし, WordNet） (Shen and Huang 2016) & 一 & 85.9 \\
\hline DRNNs （最短経路, WordNet） (Xu et al. 2016) & - & 86.1 \\
\hline BERT $_{\text {EM }}$ (BERT-Large) (Baldini Soares et al. 2019) & 82.1 & 89.2 \\
\hline
\end{tabular}

LSTM-ER モデルと DRNNs モデル，および BERT $\mathrm{EM}_{\mathrm{E}}$ モデルのスコアについては論文中から引用した. また, $\mathrm{BERT}_{\mathrm{EM}}$ モデルのみ開発事例の事例数が異なる.

構とアテンション機構を併せて導入したモデルとベースラインモデルにおける, 開発データで中 央值を記録したそれぞれのモデル間で Approximate Randomization Test (Noreen 1989)による 有意差検定を実施したところ, 有意水準 $p<0.05$ での有意な性能向上を確認した $(p=0.0197)$. また，提案モデルにおいて最短経路やZhang らによる部分木のヒューリスティックを利用した 場合の性能も上回る結果となった，ただし，本研究で実験したモデル中でテスト事例における 最高の Macro-F 值を記録したモデルは，最短経路のヒューリスティックとPair コネクションを 同時に使うモデルであった。このモデルにおける開発事例での Macro-F 值は, 三輪らが木構造 LSTM に Child-Sum 木構造 LSTM を用いた LSTM-ER モデルにおける Macro-F 值として報告 した值よりもわずかに小さいものの，その差は標準偏差以下の值であり，ほぼ同等の識別性能 であると考えられる。

各モデルにおけるP Pair コネクションの有無による識別性能の比較を表 4 に示す。表の通り， ベースラインモデルや最短経路のヒューリスティックを用いた場合は, 開発事例, テスト事例 ともに識別性能が向上した。一方で，提案手法を用いたモデルは，Pair コネクションを使用す ることで, 開発事例における Macro-F 值がどのモデルも悪化しており, 特にマスク機構とアテ 
ンション機構を同時に用いた場合で顕著である。この結果となった理由の一つとして，提案手 法とPair コネクションを同時に利用することで，モデルの表現力が過剰に大きくなり，汎化性 能が低くなった可能性が予想される.

表 3 の通り，本研究で用いたモデルの識別性能は, SPTreeやWordNet 埋め込みを用いた LSTM-ER モデルや，同じくWordNet 埋め込みを用いる DRNNs モデルと比較すると低い.さ らに, 事前学習済み BERT モデルを用いた, 依存構造を用いない関係分類モデルである $\mathrm{BERT}_{\mathrm{EM}}$ モデルはテスト事例でより高い Macro-F 值を記録している ${ }^{3}$. 今後の課題として，事前学習済 み BERTのようなより性能の高いモデルを用いた場合における, 依存構造や最短経路のヒュー リスティック，および提案手法の有効性を検証することが挙げられる.

\section{3 マスク機構におけるノイズの影響}

異なるノイズの係数パラメータ $\alpha$ ごとの生存率 $r$ の平均值の学習曲線を図 3 に示す. 図の通

表 4 Pair コネクションの有無による Macro-F 值の平均と標準偏差の比較

\begin{tabular}{l|c|c|c|c}
\hline \multirow{2}{*}{ モデル名 } & \multicolumn{2}{|c|}{ 開発事例の Macro-F 值 (\%) } & \multicolumn{2}{c}{ テスト事例の Macro-F 值 $(\%)$} \\
\cline { 2 - 5 } & Pair なし & Pair あり & Pair なし & Pair あり \\
\hline ベースライン & $81.43 \pm 0.28$ & $82.24 \pm 0.30$ & $83.17 \pm 0.16$ & $83.46 \pm 0.30$ \\
\hline +マスク機構 & $82.89 \pm 0.13$ & $82.88 \pm 0.63$ & $83.53 \pm 0.29$ & $83.44 \pm 0.29$ \\
+アテンション機構 & $82.84 \pm 0.64$ & $82.52 \pm 0.39$ & $82.95 \pm 0.43$ & $83.34 \pm 0.10$ \\
+マスク機構+アテンション機構 & $\mathbf{8 3 . 9 8} \pm \mathbf{0 . 6 5}$ & $82.89 \pm 0.44$ & $\mathbf{8 3 . 8 9} \pm \mathbf{0 . 6 4}$ & $83.20 \pm 0.29$ \\
\hline +最短経路 & $82.87 \pm 0.52$ & $\mathbf{8 3 . 4 3} \pm \mathbf{0 . 5 2}$ & $82.99 \pm 0.46$ & $\mathbf{8 4 . 0 8} \pm \mathbf{0 . 3 0}$ \\
+ Zhang らによる距離 1 の部分木 & $83.21 \pm 0.47$ & $82.46 \pm 0.35$ & $83.24 \pm 0.14$ & $83.88 \pm 0.13$ \\
\hline LSTM-ER (Child-Sum, 最短経路) & - & 83.8 & - & - \\
LSTM-ER (SPTree, 最短経路) & 84.4 & 85.1 & - & 84.4 \\
\hline
\end{tabular}

マスク機構の $\alpha$ の值は 0.7447 である. LSTM-ER モデルについては論文 (Miwa and Bansal 2016) 中か ら引用した。

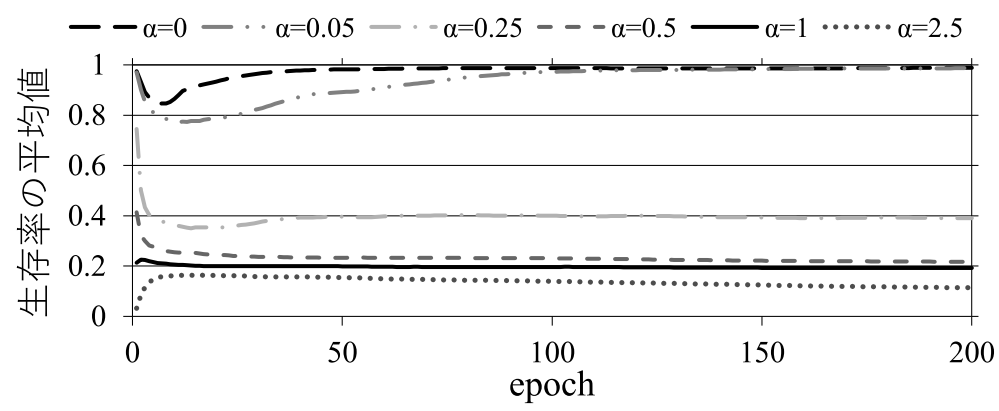

図 3 ノイズの係数パラメータ $\alpha$ ごとの生存率の平均值の学習曲線.

3 表 3 中のモデルにおいて $\mathrm{BERT}_{\mathrm{EM}}$ モデルのみ開発事例の割合が異なり, 訓練事例から 1,500 件を取り出して開発 事例としている。 
り， $\alpha$ が小さい場合や， $\alpha=0$ のとき，すなわちノイズを全く利用しないような場合では，最 終的な生存率はほぼ 1 となり，ほとんどのトークンがマスクされずそのまま利用される結果と なった，そして， $\alpha$ を大きくするに従い, 最終的な生存率の平均值が小さくなり, このパラメー タの調整によって利用するトークンの割合をコントロールすることが出来た.

$\alpha$ が小さいときの生存率が最終的にほぼ 1 になるのは, ニューラルネットワークの表現力が高 いために，ほとんどどのような入力でも損失を下げる方向に利用することができ，ほとんどの トークンを利用するように学習が進んだことが一つの理由として考えられる。また，この場合 でも，学習初期ではある程度生存率を下げる方向に学習が進み，その後逆に生存率が高くなっ ている。これは，学習初期は系列 LSTM 層からの出力ベクトルの学習がまだ十分に進んでおら ず，一部は利用しない方が損失を下げられるために一時的に生存率が下がり，その後学習が進 むにつれ損失を下げるようなパラメータにできて，一転して生存率を上げるように学習が進ん だことが理由の一つだと考えられる。一方 $\alpha$ が大きい場合は，学習初期ではほぼすべてのトー クンがマスクされている。これは，学習初期の系列 LSTM からの出力の学習がまだほとんど進 んでおらず，その後の層の計算にあまり役に立たないような表現となっているために，ほとん どがマスクされたためだと考えられる.

\section{4 マスクされるトークンの傾向}

最短経路のヒューリスティックは, 先行研究で示されている通り, モデルの識別性能を向上 できる良い経験則であり，学習から得た利用すべきマスクも，このヒューリスティックに近い ものになる可能性が高い. 実際, 開発データにおいて最も高い Macro-F 值となったモデルの平 均生存率は $20.2 \%$ となり，これは，最短経路上のトークンが文内で占める割合である $19.3 \%$ と 近い值である。そこで学習されたマスクと最短経路の間にどの程度類似度があるかを調べるた め，この二者間で残されるトークンについて Jaccard 係数を計算した．結果として Jaccard 係 数は, 5 回の試行の平均值が訓練事例で 0.821 , 開発事例では 0.826 と, マスクされないトーク ンがおよそ $20 \%$ あることから考えて非常に高い值となり，提案モデルは最短経路のヒューリ スティックに非常に近いマスクを学習から自動で獲得したといえる。さらに，提案モデルの異 なる試行ごとで得られたマスク間の Jaccard 係数は平均で 0.926 と, 最短経路との間の Jaccard 係数よりさらに高い值となっており，モデルは最短経路そのものとは少し異なる規則を学習す るという結果になった。

表 5 にいくつかの開発事例における最短経路上のトークンとマスク機構によって残されたトー クンの例を示す。この例はマスク機構とアテンション機構を併せて導入したモデルによる結果 であり，このモデルに併せてベースラインモデルで最短経路のヒューリスティックを用いたモ デルのそれぞれ 5 回の施行において最も多く予測した関係ラベルとその回数も示した. マスク 機構により残されたトークンについては，5回の施行で 3 回以上残されたトークンのみを表示 
表 5 最短経路上のトークンとマスク機構により残されたトークンの例と, 対応するそれぞれのモデルの 予測

\begin{tabular}{|c|c|c|c|}
\hline 入力 & \multicolumn{3}{|c|}{ A portion of the ethernet cable ${ }_{e 1}$ 's outer insulation ${ }_{\mathrm{e} 2}$ is in the connector as well. } \\
\hline 正解 & \multicolumn{3}{|l|}{ Reversed-Component-Whole } \\
\hline 最短経路 & cable, insulation & 予測 & Component-Whole （5 回） \\
\hline マスク機構 & cable, 's, insulation & 予測 & Reversed-Component-Whole (5 回) \\
\hline 入力 & \multicolumn{3}{|c|}{ The doctor implanted an $\underline{\text { injection }}_{\mathrm{e} 1}$ into three vertical glabellar furrows 2 . } \\
\hline 正解 & \multicolumn{3}{|l|}{ Entity-Destination } \\
\hline 最短経路 & implanted, injection, furrows & 予測 & Other (4 回) \\
\hline マスク機構 & injection, into, glabellar, furrows & 予測 & Entity-Destination （5 回） \\
\hline 入力 & \multicolumn{3}{|c|}{ China sent the premier $_{\mathrm{e} 1}$ to the meeting ${ }_{\mathrm{e} 2}$ on the climate change. } \\
\hline 正解 & \multicolumn{3}{|l|}{ Entity-Destination } \\
\hline 最短経路 & sent, premier, to, meeting & 予測 & Entity-Destination （5 回） \\
\hline マスク機構 & premier, to, meeting & 予測 & Other （3 回） \\
\hline 入力 & \multicolumn{3}{|c|}{$\begin{array}{l}\text { An important aim concerning enamel } \underline{e}_{1} \text { and dentin } \underline{\text { erosion }}_{\mathrm{e} 2} \text { is to identify agents } \\
\text { that might protect the tooth surface from demineralization }\end{array}$} \\
\hline 正解 & \multicolumn{3}{|c|}{ Other } \\
\hline 最短経路 & enamel, erosion & 予測 & Other （5 回） \\
\hline マスク機構 & enamel, and, dentin, erosion, from & 予測 & Cause-Effect （4 回） \\
\hline 入力 & \multicolumn{3}{|c|}{ The first tea $\underline{\mathrm{e}} \underline{\text { bags }}_{\mathrm{e} 2}$ were made from hand-sewn silk muslin bags. } \\
\hline 正解 & \multicolumn{3}{|l|}{ Content-Container } \\
\hline 最短経路 & tea, bags & 予測 & Reversed-Entity-Origin （5 回） \\
\hline マスク機構 & tea, bags & 予測 & Content-Container （4 回） \\
\hline 入力 & \multicolumn{3}{|c|}{ On 17 May 2005 , the committee held a hearing ${ }_{\mathrm{e} 1}$ concerning specific allegations ${ }_{\mathrm{e}} 2$} \\
\hline 正解 & \multicolumn{3}{|l|}{ Message-Topic } \\
\hline 最短経路 & hearing, concerning, allegations & 予測 & Message-Topic （5 回） \\
\hline マスク機構 & hearing, concerning, allegations & 予測 & Other （3 回） \\
\hline
\end{tabular}

e1 と e2 は注目エンティティを示し, 予測は 5 回の施行で最も多く選ばれたものとその回数を表示した. 関係の向きは常に e 1 から $\mathrm{e} 2$ へとし, 逆向きの関係ラベルには Reversed のプレフィックスを付けている.

している．表中の上二つの例のように，マスク機構は最短経路上には存在しない所有格の $s$ や intoのような単語を残すよう学習し, 最短経路を用いたモデルでは正しく予測できなかった事 例について正解することができたケースが確認された。逆に三番目の例では最短経路上に存在 する sent を残さず，最短経路を用いたモデルでは正しく予測できた事例について誤ってしまう ケースも確認された。また，四番目の例では注目エンティティペアに無関係な from を残し，予 測もCause-Effect（原因と結果の関係）を予測してしまうといった，無関係な言及に注目してし まったがために間違えてしまうケースも見つかった。この一方で，下二つの例のように最短経 路と同じトークンを残しながら異なる予測を多くするようになった事例もいくつか確認された. 
表 6 品詞夕グごとのマスク機構が残す単語の数

\begin{tabular}{|c|c|c|c|c|c|c|c|c|c|c|c|c|}
\hline \multirow{3}{*}{ 品詞 } & \multicolumn{6}{|c|}{ 訓練事例 } & \multicolumn{6}{|c|}{ 開発事例 } \\
\hline & \multicolumn{3}{|c|}{ 全単語 } & \multicolumn{3}{|c|}{ エンティティ以外 } & \multicolumn{3}{|c|}{ 全単語 } & \multicolumn{3}{|c|}{ エンティティ以外 } \\
\hline & 単語数 & $\mathrm{SP}$ & 生存数 & 単語数 & $\mathrm{SP}$ & 生存数 & 単語数 & $\mathrm{SP}$ & 生存数 & 単語数 & $\mathrm{SP}$ & 生存数 \\
\hline NN & 27,308 & 11,305 & 11,632 & 16,950 & 947 & 1,274 & 2,989 & 1,207 & 1,241 & 1,862 & 80 & 114 \\
\hline NNS & 8,967 & 3,937 & 3,993 & 5,372 & 342 & 398 & 1,072 & 457 & 465 & 655 & 40 & 48 \\
\hline NNP & 4,605 & 125 & 224 & 4,524 & 44 & 143 & 524 & 14 & 25 & 515 & 5 & 16 \\
\hline NNPS & 160 & 9 & 10 & 153 & 2 & 3 & 11 & 3 & 3 & 8 & 0 & 0 \\
\hline $\mathrm{DT}$ & 18,778 & 55 & 43 & 18,778 & 55 & 43 & 2,094 & 7 & 5 & 2,094 & 7 & 5 \\
\hline IN & 17,590 & 5,760 & 5,926 & 17,589 & 5,759 & 5,925 & 2,021 & 640 & 654 & 2,021 & 640 & 654 \\
\hline JJ & 9,809 & 269 & 349 & 9,679 & 139 & 219 & 1,174 & 38 & 44 & 1,154 & 18 & 24 \\
\hline JJR & 250 & 6 & 9 & 246 & 2 & 5 & 34 & 1 & 0 & 34 & 1 & 0 \\
\hline JJS & 242 & 13 & 3 & 242 & 13 & 3 & 35 & 2 & 0 & 35 & 2 & 0 \\
\hline . & 7,203 & 0 & 0 & 7,203 & 0 & 0 & 802 & 0 & 0 & 802 & 0 & 0 \\
\hline , & 4,230 & 2 & 13 & 4,230 & 2 & 13 & 528 & 1 & 2 & 528 & 1 & 2 \\
\hline $\mathrm{VBN}$ & 4,585 & 1,943 & 1,850 & 4,573 & 1,931 & 1,838 & 549 & 235 & 227 & 548 & 234 & 226 \\
\hline VBD & 4,529 & 1,351 & 1,073 & 4,525 & 1,347 & 1,069 & 543 & 150 & 124 & 543 & 150 & 124 \\
\hline VBZ & 3,851 & 955 & 903 & 3,818 & 922 & 870 & 391 & 81 & 71 & 390 & 80 & 70 \\
\hline VBG & 2,328 & 546 & 457 & 2,260 & 478 & 389 & 287 & 66 & 53 & 277 & 56 & 43 \\
\hline VBP & 1,950 & 346 & 300 & 1,906 & 302 & 256 & 224 & 37 & 32 & 221 & 34 & 29 \\
\hline VB & 1,798 & 218 & 132 & 1,748 & 168 & 82 & 190 & 23 & 14 & 182 & 15 & 6 \\
\hline $\mathrm{CC}$ & 3,635 & 1 & 29 & 3,635 & 1 & 29 & 438 & 0 & 2 & 438 & 0 & 2 \\
\hline $\mathrm{RB}$ & 3,131 & 46 & 82 & 3,127 & 42 & 78 & 326 & 2 & 4 & 326 & 2 & 4 \\
\hline TO & 2,321 & 292 & 322 & 2,321 & 292 & 322 & 269 & 37 & 37 & 269 & 37 & 37 \\
\hline PRP & 2,179 & 3 & 50 & 2,179 & 3 & 50 & 252 & 0 & 7 & 252 & 0 & 7 \\
\hline PRP\$ & 1,480 & 1 & 41 & 1,480 & 1 & 41 & 163 & 0 & 8 & 163 & 0 & 8 \\
\hline $\mathrm{CD}$ & 1,642 & 39 & 53 & 1,638 & 35 & 49 & 176 & 4 & 4 & 176 & 4 & 4 \\
\hline WDT & 812 & 0 & 174 & 812 & 0 & 174 & 86 & 0 & 15 & 86 & 0 & 15 \\
\hline WRB & 349 & 0 & 1 & 349 & 0 & 1 & 36 & 0 & 0 & 36 & 0 & 0 \\
\hline WP & 295 & 0 & 68 & 295 & 0 & 68 & 30 & 0 & 8 & 30 & 0 & 8 \\
\hline WP\$ & 17 & 0 & 1 & 17 & 0 & 1 & 0 & 0 & 0 & 0 & 0 & 0 \\
\hline POS & 697 & 0 & 104 & 697 & 0 & 104 & 72 & 0 & 11 & 72 & 0 & 11 \\
\hline $\mathrm{RP}$ & 382 & 0 & 42 & 382 & 0 & 42 & 50 & 0 & 8 & 50 & 0 & 8 \\
\hline $\mathrm{MD}$ & 255 & 4 & 3 & 251 & 0 & 0 & 22 & 0 & 0 & 22 & 0 & 0 \\
\hline -LRB- & 247 & 0 & 0 & 247 & 0 & 0 & 32 & 0 & 0 & 32 & 0 & 0 \\
\hline -RRB- & 247 & 0 & 0 & 247 & 0 & 0 & 32 & 0 & 0 & 32 & 0 & 0 \\
\hline ”及び ‘ & 457 & 0 & 0 & 457 & 0 & 0 & 60 & 0 & 0 & 60 & 0 & 0 \\
\hline : & 226 & 0 & 0 & 226 & 0 & 0 & 31 & 0 & 0 & 31 & 0 & 0 \\
\hline $\mathrm{RBR}$ & 108 & 3 & 0 & 108 & 3 & 0 & 14 & 0 & 0 & 14 & 0 & 0 \\
\hline RBS & 80 & 0 & 0 & 80 & 0 & 0 & 9 & 0 & 0 & 9 & 0 & 0 \\
\hline $\mathrm{EX}$ & 108 & 0 & 1 & 108 & 0 & 1 & 10 & 0 & 0 & 10 & 0 & 0 \\
\hline PDT & 59 & 0 & 1 & 59 & 0 & 1 & 5 & 0 & 0 & 5 & 0 & 0 \\
\hline FW & 58 & 2 & 2 & 57 & 1 & 1 & 6 & 1 & 1 & 5 & 0 & 0 \\
\hline$\$$ & 37 & 2 & 1 & 37 & 2 & 1 & 4 & 1 & 0 & 4 & 1 & 0 \\
\hline $\mathrm{UH}$ & 6 & 0 & 0 & 6 & 0 & 0 & 1 & 0 & 0 & 1 & 0 & 0 \\
\hline SYM & 5 & 0 & 0 & 5 & 0 & 0 & 0 & 0 & 0 & 0 & 0 & 0 \\
\hline LS & 4 & 0 & 0 & 4 & 0 & 0 & 1 & 0 & 0 & 1 & 0 & 0 \\
\hline
\end{tabular}

単語数は各事例に含まれる全単語数を, SP は最短経路上に含まれる単語数を, 生存数はマスク機構が残 した単語の数を表す. 
提案モデルのうちで最高の Macro-F 值を記録したモデルにおける，品詞タグごとのマスク機 構によって残される単語の数を表 6 に示す. 表中の単語数が各事例に含まれる単語の総数で, $\mathrm{SP}$ はそのうち最短経路上に含まれるもの，生存数はマスク機構が残した単語の数である．表の 通り，マスク機構によって残される単語の数は最短経路上に含まれる単語の数とかなり近いが, 名詞 (NN, NNS, NNP, NNPS) は僅かに多く, 逆に動詞 (VBN, VBD, VBZ, VBG, VBP, VB) は 僅かに少ないなど，細かな違いがみられる，特に，最短経路の外側になってしまう所有格の $s$ な ど (POS, possessive ending) や, Particle (RP), ヘッドにならなかった what な゙ (WDT, WRB, $\mathrm{WP}, \mathrm{WP} \$)$ が一部生存しており，このことから狙い通りマスク機構が最短経路外の情報を利用 していることが確認できる.

マスク機構の処理は中間出力のそれぞれを確信度に基づきマスクするのみであるので，その 後の計算に用いられる構造は，異なる依存関係セットを用いる Universal Dependenciesのよう な別の依存構造の表現形式を用いても適用可能である。その一方で, マスク機構に続く層が入 力に期待する構造から外れるようなマスクを行わないように，利用する構造に合わせた，その 構造をよく表現する情報をマスク機構に入力するべきであると考えられる。今回は式 (3), (9) の通り，双方向 LSTM の出力，および係り受けと相対距離の埋め込みべクトルを入力に用いた が，よりよい依存構造木を表すような表現や，ほかの構造におけるよい表現について検討する 必要があると考えられる。

\section{5 おわりに}

本稿では, 関係分類において重要なトークンの判別規則を学習を通じて獲得するマスク機構を 提案した。ベースラインモデルに提案機構を導入した関係分類モデルは, 最短経路のヒューリ ステイックを用いた場合の識別性能を上回り，依存木全体を用いた場合の識別性能に対しては 有意な性能向上を達成した。提案機構により学習されたマスクは最短経路のヒューリスティッ クに近いものが自ずと学習される一方で, 所有格の $s$ などの最短経路上に存在しないトークン を利用するようになった。ささらに，異なる学習試行ごとで得られたマスク間の類似度は，最短 経路との間の類似度よりも高く, 最短経路そのものとは一部異なる規則が学習されやすいこと が確認された。今後の課題として, BERTのような, より性能の高いモデルにおける最短経路 のヒューリスティックの有効性の調査と, そのようなモデルへの提案機構の導入が挙げられる.

\section{参考文献}

Baldini Soares, L., FitzGerald, N., Ling, J., and Kwiatkowski, T. (2019). "Matching the Blanks: Distributional Similarity for Relation Learning." In Proceedings of the 57th Annual Meeting 
of the Association for Computational Linguistics, pp. 2895-2905.

Bunescu, R. and Mooney, R. (2005). "A Shortest Path Dependency Kernel for Relation Extraction." In Proceedings of Human Language Technology Conference and Conference on Empirical Methods in Natural Language Processing, pp. 724-731.

Chen, D. and Manning, C. (2014). "A Fast and Accurate Dependency Parser using Neural Networks." In Proceedings of the 2014 Conference on Empirical Methods in Natural Language Processing (EMNLP), pp. 740-750.

Culotta, A. and Sorensen, J. (2004). "Dependency Tree Kernels for Relation Extraction." In Proceedings of the 42nd Annual Meeting of the Association for Computational Linguistics (ACL-04), pp. 423-429.

Devlin, J., Chang, M.-W., Lee, K., and Toutanova, K. (2019). "BERT: Pre-training of Deep Bidirectional Transformers for Language Understanding." In Proceedings of the 2019 Conference of the North American Chapter of the Association for Computational Linguistics: Human Language Technologies, Volume 1 (Long and Short Papers), pp. 4171-4186.

Fellbaum, C. (1998). WordNet: An Electronic Lexical Database. MIT Press.

Gers, F. A., Schraudolph, N. N., and Schmidhuber, J. (2002). "Learning Precise Timing with LSTM Recurrent Networks." Journal of Machine Learning Research, 3 (Aug), pp. 115-143.

Hendrickx, I., Kim, S. N., Kozareva, Z., Nakov, P., Ó Séaghdha, D., Padó, S., Pennacchiotti, M., Romano, L., and Szpakowicz, S. (2010). "SemEval-2010 Task 8: Multi-Way Classification of Semantic Relations between Pairs of Nominals." In Proceedings of the 5th International Workshop on Semantic Evaluation, pp. 33-38.

Jang, E., Gu, S., and Poole, B. (2017). "Categorical Reparameterization with Gumbel-Softmax." Computing Research Repository, arXiv:1611.01144. version 5.

Klein, A., Falkner, S., Mansur, N., and Hutter, F. (2017). "RoBO: A Flexible and Robust Bayesian Optimization Framework in Python." In NIPS 2017 Bayesian Optimization Workshop.

Miwa, M. and Bansal, M. (2016). "End-to-End Relation Extraction using LSTMs on Sequences and Tree Structures." In Proceedings of the 54th Annual Meeting of the Association for Computational Linguistics (Volume 1: Long Papers), pp. 1105-1116.

Noreen, E. W. (1989). Computer-Intensive Methods for Testing Hypotheses. Wiley New York.

Peters, M., Neumann, M., Iyyer, M., Gardner, M., Clark, C., Lee, K., and Zettlemoyer, L. (2018). "Deep Contextualized Word Representations." In Proceedings of the 2018 Conference of the North American Chapter of the Association for Computational Linguistics: Human Language Technologies, Volume 1 (Long Papers), pp. 2227-2237. 
Shen, Y. and Huang, X. (2016). "Attention-Based Convolutional Neural Network for Semantic Relation Extraction." In Proceedings of COLING 2016, the 26th International Conference on Computational Linguistics: Technical Papers, pp. 2526-2536.

Srivastava, N., Hinton, G., Krizhevsky, A., Sutskever, I., and Salakhutdinov, R. (2014). "Dropout: A Simple Way to Prevent Neural Networks from Overfitting." Journal of Machine Learning Research, 15, pp. 1929-1958.

Tai, K. S., Socher, R., and Manning, C. D. (2015). "Improved Semantic Representations From Tree-Structured Long Short-Term Memory Networks." In Proceedings of the 53rd Annual Meeting of the Association for Computational Linguistics and the 7th International Joint Conference on Natural Language Processing (Volume 1: Long Papers), pp. 1556-1566.

Vaswani, A., Shazeer, N., Parmar, N., Uszkoreit, J., Jones, L., Gomez, A. N., Kaiser, Ł., and Polosukhin, I. (2017). "Attention is All you Need." In Advances in Neural Information Processing Systems 30, pp. 5998-6008.

Xu, Y., Jia, R., Mou, L., Li, G., Chen, Y., Lu, Y., and Jin, Z. (2016). "Improved Relation Classification by Deep Recurrent Neural Networks with Dyerata Augmentation." In Proceedings of COLING 2016, the 26th International Conference on Computational Linguistics: Technical Papers, pp. 1461-1470.

Xu, Y., Mou, L., Li, G., Chen, Y., Peng, H., and Jin, Z. (2015). "Classifying Relations via Long Short Term Memory Networks along Shortest Dependency Paths." In Proceedings of the 2015 Conference on Empirical Methods in Natural Language Processing, pp. 1785-1794.

Zhang, Y., Qi, P., and Manning, C. D. (2018). "Graph Convolution over Pruned Dependency Trees Improves Relation Extraction." In Proceedings of the 2018 Conference on Empirical Methods in Natural Language Processing, pp. 2205-2215.

\section{略歴}

辻村 有輝：2016 年豊田工業大学工学部卒業. 2018 年豊田工業大学大学院修士

課程修了. 現在, 豊田工業大学大学院工学研究科博士課程に在学中.

三輪誠：2008 年東京大学大学院博士課程修了. 博士 (科学)。東京大学, マ ンチェスター大学を経て, 2014 年より豊田工業大学知能数理研究室准教授.

$\mathrm{ACL}$, 情報処理学会, 言語処理学会, 人工知能学会各会員.

佐々木 裕：1988 年筑波大学修士課程理工学研究科修了. 2000 年同大学より博 士 (工学) 授与. NTT 研究所, ATR, マンチェスター大を経て, 現在, 豊田 工業大学教授. 言語処理学会等会員. 
（2019 年 11 月 1 日 受付）

(2020 年 2 月 8 日 再受付)

(2020 年 2 月 25 日 採録) 